\title{
TENDENCIES IN SETTLEMENT PLANNING IN LIGHT OF THE IDEA OF 'A VILLAGE IN A PARK SPACE' IN THE OGRODZIENIEC MUNICIPALITY
}

TENDENCJE W KSZTAŁTOWANIU OSADNICTWA W ŚWIETLE IDEI „WSI W KRAJOBRAZIE PARKOWYM" NA TERENACH GMINY OGRODZIENIEC

\author{
Ingeborga Cygankiewicz \\ dr inż. arch. \\ Author's Orcid number:0000-0001-5271-5321
}

Jan Łaś

dr inż. arch.

Author's Orcid number:0000-0003-1209-131X

Cracow University of Technology, Poland

The Faculty of Architecture

Department of Spatial Planning, Urban and Rural Design

\begin{abstract}
This paper discusses the planning and spatial transformation of the municipality of Ogrodzieniec in the context of the idea of 'a village in a park space'. The rural area of the Ogrodzieniec municipality has undergone significant landscape transitions over the past several decades. The dynamic development of single-family housing has generated the greatest amount of functio-spatial and compositional and landscape problems. The idea of 'a village in a park space' is to counter these negative development trajectories. It defines general perspectives of rural area development in a spirit of sustainable development.
\end{abstract}

Keywords: park space, rural areas, sanation of rural areas.

\section{STRESZCZENIE}

W artykule podjęto rozważania nad planistyczno-przestrzennymi przekształceniami gminy Ogrdzieniec w kontekście idei „wsi w krajobrazie parkowym”. Tereny wiejskie gminy Ogrodzieniec w przeciągu ostatnich kilkudziesięciu lat uległy znacznym przemianom krajobrazowym. Żywiołowo rozwijające się mieszkalnictwo jednorodzinne wygenerowało najwięcej problemów funkcjonalnoprzestrzennych i kompozycyjno-krajobrazowych. Idea „wsi w krajobrazie parkowym” przeciwstawia się wspomnianym wyżej negatywnym kierunkom rozwoju. Wytycza ogólne perspektywy zagospodarowania obszarów wiejskich w duchu zrównoważonego rozwoju.

Słowa kluczowe: krajobraz parkowy, obszary wiejskie, sanacja wsi. 


\section{INTRODUCTION}

In the literature, numerous researchers expressed grave concern about the trajectory that the transitions that Polish rural areas are undergoing, specifically about settlement tendencies that are implemented without respect for beauty and that follow rather peculiar utility criteria. The disappearance of traditional rural functions or the lack of future development perspectives for agriculture results in rural areas being mostly treated as a collection of various assets that are mostly seen as useful for urbanisation. One particular threat that can lead to the irreversible loss of the landscape qualities of rural areas is extensive and chaotic settlement for non-agrarian populations, which comprises an increasing share of contemporary rural residents. Applicable planning and spatial documents lack vision and ideas that match contemporary development tendencies, especially those that lead to consequences that are negative from a wildlife and landscape perspective.

Inspiration for contemporary solutions can be sought in the idea of 'a village in a park space' (ViaPS). It can serve as a tool in engaging in reparatory planning efforts. In this study, we made an attempt to define whether this idea is relevant as a course of action in planning and spatial efforts, and to determine the chances and necessary conditions for its implementation in the Ogrodzieniec municipality and in other rural areas within reach of urbanisation pressure.

\subsection{Research methods}

This paper presents an outline of the shaping of rural areas in the spirit of a village in a park space (ViaPS). It includes an overview of changes that took place in the rural areas of Ogrodzieniec that had a significant impact on the spatial reception of the village.

Based on the literature and an analysis of projects, we determined the criteria of ViaPS. We have presented an analysis of selected settlement and landscape characteristics that are key from the standpoint of ViaPS, comparing this data against demographic factors. We have presented a summary in the form of three versions of the rural area's transition - a realist, moderate and radical one.

\subsection{The idea of 'a village in a park space' (ViaPS) - an overview}

The idea of 'a village in a park space' is not a statutory form of landscape preservation. It is merely a concept of planning the rural landscape that is compliant with the precepts of sustainable development. It is not a new idea, as its elements could be found in various studies and designs since the nineteenth century.

In this paper, the authors focused on the outline of this idea, as drawn up by the Krakow school of landscape architecture (Z. Nowák, J. Bogdanowski, M. Łuczyńska-Bruzda, K. Dąbrowska-Budziło, Z. Myczkowski, A. Böhm). It should be highlighted that numerous studies by the Krakow school concerned the area of the Krakow-Częstochowa Upland, and even strictly the area of the Ogrodzieniec municipality, which the authors view as justification for referring to their findings.

The precursor of the idea, although it was not yet named at the time but nevertheless included a range of its elements, is considered to be General Dezydery Chłapowski, who, inspired by travels to England and Scotland, established a model estate in the township of Turew near Poznan. Over time, many - including non-farmers - came to see it as a model of a harmonious combination of beauty and utility, and an example of planned landscape transformation for economic purposes (Chłapowski 1852, IInicki 2004, p.163-164).

The notion of the 'park space' was first formulated in 1976 by Professor Janusz Bogdanowski in his book Kompozycja i planowanie $w$ architekturze krajobrazu. The main value of this vision of a model rural landscape was to be compact rural development with features of regional vernacular architecture, set against a background of fields and inter-field tree stands, further mutually linked via a safe road network, significant to vehicular tourism and hiking.

Professor Mieczysław Chowaniec devoted a significant portion of his academic work to the previously mentioned issues of sanating the countryside (Chowaniec 1960, 1963, 1967, 1986). The modernisation models developed by Professor Chowaniec were based on freeing up the open 
landscape of the countryside from scattered development. New buildings were to be concentrated along strips parallel to existing development and cover an area within a 10-minute pedestrian access isochrone from a set social and service centre.

Proposals following a similar spirit were also formulated by August Bocheński (Rzymowski and Bocheński 1963, Bocheński 1968). The precepts of the recomposition of the rural landscape were based on introducing strip development and complexes of greenery tied with farm-type settlement plots. Newly designed lines of trees and bushes were to not only improve microclimate conditions and enhance the profitability of farms, but also to increase the aesthetic and landscape value of wider areas and mask farms scattered around the landscape.

An attempt at combining elements of the idea of a village in a park space, scattered across numerous academic works, appeared in Marek Kowicki's Wieś przyszłości jako alternatywa osadnicza miasta (1997), where the problem of housing for the non-farming population was prominently accentuated. Kowicki noted that cases of high-density non-agrarian settlement had existed in Polish rural territories (e.g. in the form of trade and commercial towns) and that such a system was not being contemporarily implemented. ${ }^{1}$

The authors note that the literature they analysed featured a general consensus concerning the postulate for a radical remodelling of rural settlement areas as a base condition for the modernisation of the development of rural areas that would harmoniously combine Beauty with Utility.

The model of concentrated settlement in rural areas that corresponds to the assumptions of the idea of 'a village in a park space' and other proposals linked with the correct development of rural areas, is being implemented in Western European countries, especially in areas where land is prized the most due to its deficit.

One case of well-informed and rational manmade land management are the Netherlands. The experience gained by the country's inhabitants in the process of the arduous reclamation of land from a marine depression aided them in conducting proper spatial development. This policy was prominently tied with respecting open areas free from development. In practice, this meant demarcating new areas for development only when existing buildable land was fully utilised.

The new needs of a population that desires proximity to nature while also demanding the comforts of urban life became an inspiration for innovative structures in Haverleij, where a project of modern housing complexes for non-agrarian residents was completed. The proposal of concentrating development in a form that referenced medieval castles or fortified towns was put forth by architect Sjoerd Soeters and landscape architect Paul van Beek. The project combines comfort, safety and space. A purposively designed varied landscape, rich in meadows, reed fields and extensive gardens, golf courses and bodies of water, produces an impression of the countryside. Concentrated development, connected with a circulation network around which there are open spaces, is a settlement model that provides residents with close contact with nature. Perhaps this solution might appear too radical to be currently implemented in Poland, yet it introduces an experience that could result in bold and ingenious projects in the future.

Julianadorp is a similar settlement. Designed in a different manner to that of Haverleij, as it is based on a sequence of quite loosely placed, sequential interiors, from the inside it presents itself as a compact complex against the background of an open rural landscape.

Another example that is a sign of the need to create structures that are well-defined in spatial and planning terms is Poundbury near Dorchester, England (Krier 2011). It is a compact complex with a clearly defined border that separates development from the open landscape. To achieve the desired atmosphere of this place, the designers decided to very clearly define the buildings, down to their architectural detail.

1 The author used the case of Frampol in calculating the potential building footprint for the non-agrarian population. He assumed a scale of land demand for a town being around 250 residents/ha, following the principle of 'low and dense', which resulted in 1500-2000 residents on an area of around 6-8 ha. It turned out that, with the assumed maximum size of the town, around 15 ha, its territory could fit into a $400 \times 400 \mathrm{~m}$ plot, which is smaller than Frampol $(500 \times 500 \mathrm{~m})$. (Kowicki, Wieś przyszłości jako alternatywa osadnicza miasta, 1997, p. 162). 
One model of an exceptionally lasting settlement form is the village of Milton Abbas in Dorset, England (Sharp, 1946, p.22). Built in 1786, it retained its compact development due to a ring-shaped park that effectively protected it from development sprawling beyond its pre-set planning scheme.

In many areas of Europe, agrarian development is dispersed across farmland in a planned manner, which is confirmed in M. Kowicki's assumptions on the planning and spatial structure of settlement for agrarian populations. Cases of this type of planned dispersal can be easily found in the Netherlands, Austria, Denmark, Germany, and other countries that cultivate good agriculture (Kowicki 2010).

\subsection{The criteria of the idea of 'a village in a park space' (ViaPS)}

Based on theoretical studies and projects, we collected the following criteria for the correct development of rural areas that would harmoniously combine Beauty with Utility (pursuant to the idea of 'a village in a park space'):

1. the clear definition of buildable area geometries in planning documents and projects, 2. legibly delineated land-use division lines between buildable and agricultural land, the planned scattering of development for the agrarian population, synchronised with the size of farmland, 3 . development of a settlement model for the non-agrarian population in the form of towns (pre-existing and founded in cruda radice), 4. the demarcation and architectural construction of village centres as 'reference points' for functional zoning in rural areas, 5 . the introduction of functional zoning principles within the village's territory: a zone of the conservation of heritage planning and spatial layouts, wildlife and landscape complexes, etc., 6. the preservation of pre-existing assets (manorial and rural parks, avenues lined with trees), 7. the demarcation of zones for individual and mass recreation, 8. coupling the system of utility roads with the system of tourist routes and the inter-field greenery system, 9. attention to preserving the natural landscape in specific areas and of ecological uses (forest areas, swamps, forest meadows, etc.), 10. supporting biodiversity associated with the system of inter-field greenery, field paths, fire stations, wind protection strips, the pattern of fields, 11. stimulating the development of ecological or integrated agriculture, 12. attention to compositional and landscape assets: shaping panoramas, attention to landscape landmarks, the interiors of villages, colour and material harmony, creating observation points and sequences, 13 . fostering economic conditions that encourage the cultivation of wildlife, landscape and cultural assets, 14 . treating the work of farmers as not confined solely to economic categories, and appreciating their role as caretakers of the landscape.

\section{PLANNING, SPATIAL AND ARCHITECTURAL TRANSITIONS IN THE OGRODZIENIEC MUNICIPALITY}

\subsection{Determinants}

The municipality of Ogrodzieniec, due to the high value of its surrounding landscape, is among regions that are attractive in terms of settlement. This is determined by, among others, its location in close proximity to three main agglomerations of southern Poland: Krakow (60 km), Katowice $(55 \mathrm{~km})$ and Częstochowa $(50 \mathrm{~km})$. The territory of the Municipality is within the boundaries of the Silesian Voivodeship's Jura Landscape Parks Complex, as well as the Eagles' Nests Landscape Park. Among its cultural assets, those of the highest rank are represented by the ruins of the fourteenth-century Ogrodzieniec Castle that tower over the area. The municipality consists of the town of Ogrodzieniec and ten sołectwa (rural administrative units): Fugasówka-Markowizna, Giebło, Giebło Kolonia, Gulzów, Kiełkowice, Mokrus, Podzamcze, Ryczów, Ryczów Kolonia, ŻelazkoŚrubarnia.

The choice of the Ogrodzieniec municipality as the field of study was motivated by the occurrence of nearly all determinants distinctive of Polish villages within its limits. Among these, the most important are: 
- The continued persistence of relatively active agricultural functions that are nevertheless without clear development perspectives due to there being no clear proposals of agriculture modernisation (a change in the approach to land, which is seen as more valuable when used for construction instead of farming,

- The growing number of non-agrarian residents in rural areas (typical evidence of urban sprawl: commuting, rural areas as commuter towns, migration of the urban population to rural areas, the weakening of socio-territorial bonds, etc.),

- The presence of recreational functions and potential for their intensification,

- Tendency towards scattered development,

- Illegibility of planning, spatial and architectural rigours,

- Exploitative forms of using rural wildlife and landscape assets instead of guardianship-based ones.

\subsection{Historical planning and spatial transitions}

The process of territorial settlement and the emergence of the oldest and most significant settlement complexes currently located within the Ogrodzieniec municipality took place already in the fourteenth century, while the essential layout of the settlement network was formed at the turn of the twentieth century (Cygnarowski and Jagodziński, 1991).

According to archaeological studies, the areas that were settled the earliest included: Podzamcze (which functioned very early as a complex auxiliary to the castle), Kiełkowice, Giebło (its church existed already in the middle of the twelfth century) and Ryczów. The oldest settlements in the municipality also include Ogrodzieniec (it had a parish church in 1337) and Mokrus.

The pace of transitions became quicker when, in the beginning of the twentieth century, as a result of the parcellation of large landed estates and land consolidation, additional settlement complexes appeared: Kolonia Ryczów, Kolonia Gieblo, Mokrus and small clusters of scattered development in other complexes. Gulzów also took shape at this time, and had previously functioned as a grange of the Pilica estate. The Markowizna and Fulgasówka settlement complexes were the latest to form. These were strong stimuli for the scattering of development in rural areas. They became further enhanced as a result of land consolidation and parcellation performed immediately before the Second World War. However, despite this, the scattering of development, particularly severe in the sołectwo of Kielkowice, did not bring with it excessively drastic compositional and landscape consequences. This was due to the fact that the scale of individual buildings erected in the village did not change and neither did their architectural form, which in many cases continued to copy traditional functional, spatial, material and structural solutions in a slightly altered form.

The greatest breakthrough that brought with it significant spatial, planning and architectural changes took place in the years 1960-1980. It was characterised by a rapid pace of housing development, supported by loaning policies and pre-made design solutions. The dynamic growth of development that was not integrated with its surroundings was the main factor that shaped the landscape of the countryside at the time.

In the 1980s, the manner of forming development had a profound impact on the planning and spatial character of the Ogrodzieniec municipality. The provision in the Detailed Spatial Development Plan Study of the Ryczów Sołectwo can be seen as a confirmation of this, as it concerns the issue of the design of housing buildings and landscape conservation and suggests the irrevocable loss and destruction of the wildlife and cultural assets of this area: 'At present, poor decisions on the siting, form and function of buildings have led to an unfavourable scattering of housing development by its placement at points in the landscape seen as attractive, which, in light of the current tendency to build three-storey cubic massings, has ultimately tarnished the landscape values of the village and its surroundings'. (Gałkowski and Tomaszewska, 1984, p. 70).

The period after the 1990s and the present has brought the dynamic growth of development characterised by a diversity of architectural forms. The planning and spatial transitions of this period resulted mostly from: the ease of access to buildable land in rural areas - due to the lower cost of 
land in comparison to plots in cities, transport development and rising car traffic that directly affects the loosening of ties between one's place of residence and the workplace, and the appearance of new opportunities on the employment market and the wildlife and landscape attractiveness of rural areas, especially in comparison with the increasingly difficult ecological situation observed in cities.

\subsection{Analysis of the spatial development of rural built-up areas in the Ogrodzieniec municipality}

We performer an analysis of selected settlement and landscape characteristics found crucial from the standpoint of the ViaPS concept, based on a simplified version of the 'village charts' method' (Myczkowski, 1998) for the Ogrodzieniec municipality (fig. 1). Presented in the form of tables combined with drawings, the listing of all towns was to display: general data (administrative status, number of residents, general area within administrative limits), rural layout characteristics (outline of major developmental phases of a village, overview of major rural layout elements: typologies of the planning layout of development performed based on historical and conservation studies of the Ogrodzieniec municipality (Cygnarowski and Jagodziński, 1991), accounting for the taxonomy of settlement (Kiełczewska-Zalewska, 1972), field layout, housing building orientation on plots, architectural characteristics and landscape elements, i.e. surface waters and greenery; a scheme of the settlement layout set against the field and forest area layout; overview of selected major compositional and landscape problems of a given rural area.

We also presented an analysis of the spatial development of the Ogrodzieniec municipality's builtup area in tabular form (Fig. 2, for each sołectwo, along with the town of Ogrodzieniec), which allowed us to determine the area dimension, pace and spatial trajectories of previous changes in each of the municipality's villages over the following time sequences: 1938-1980-2000-horizon set in the Local Spatial Development Plan.

The spatial layouts of villages included in the table were characterised using M. Chilczuk's typology (Chilczuk, 1970). We assumed a division by development concentration degree, divided into the following layout types: a) compact layout, in which at least $2 / 3$ of the overall number of farms were within 20-30 m away from each other, b) concentrated, in which the distance of at least $2 / 3$ of farms (distance from residential buildings) were within 50-70 m from each other, c) scattered, where the distance between farms in 2/3 of cases was, on average, between 120 and $180 \mathrm{~m}$ or more. In search of the factors that determined the spatial development of rural settlements, we also listed the character of the locality as compliant with its current function and the one listed in municipal documents, the number of households and the percentage share of agrarian households, the soil valuation class and up-to-date, precise areas of agricultural use, fallows, forests and buildable land.

The comparison of data presented in table form led to the following conclusions about the groups of villages under study:

Our analysis of the spatial development of villages in the Ogrodzieniec municipality which showed signs of the growth of developed areas in the following timeframes: the end of the 1930s, the end of the 1970s, the beginning of the twenty-first century and planned growth, and displayed a clear increase in built-up areas in localities where the non-agrarian population predominated, while villages with a predominantly agrarian function showed the smallest relative growths. Among the 10 solectwa, we can identify which show signs of planning discipline. These include the rural complexes of Gulzów, Mokrus and Giebło. Development was observed to form compact and easily identifiable forms in the landscape in these areas. The data collected also indicates that (Ogrodzieniec MaTH) they are localities where the share of farms was the highest in the entire municipality. Therefore, the practice of agriculture aids in protecting land suitable for this use from development.

2 Simplified village charts were prepared based on an instruction for detailed metrics, Wieś-Ruralistyka 7.1, based on socalled Village charts (detailed-M. Łuczyńska-Bruzda, Z. Myczkowski et al., 1988; simplified-J. Bogdanowski, 1989) [in:] Ochrona wartości krajobrazu i środowiska kulturowego, Collective work under the direction of Z. Myczkowski, 1998, Krajobrazy 18 (30), Ośrodek Ochrony Zabytkowego Krajobrazu, Narodowa Instytucja Kultury, Warszawa). 


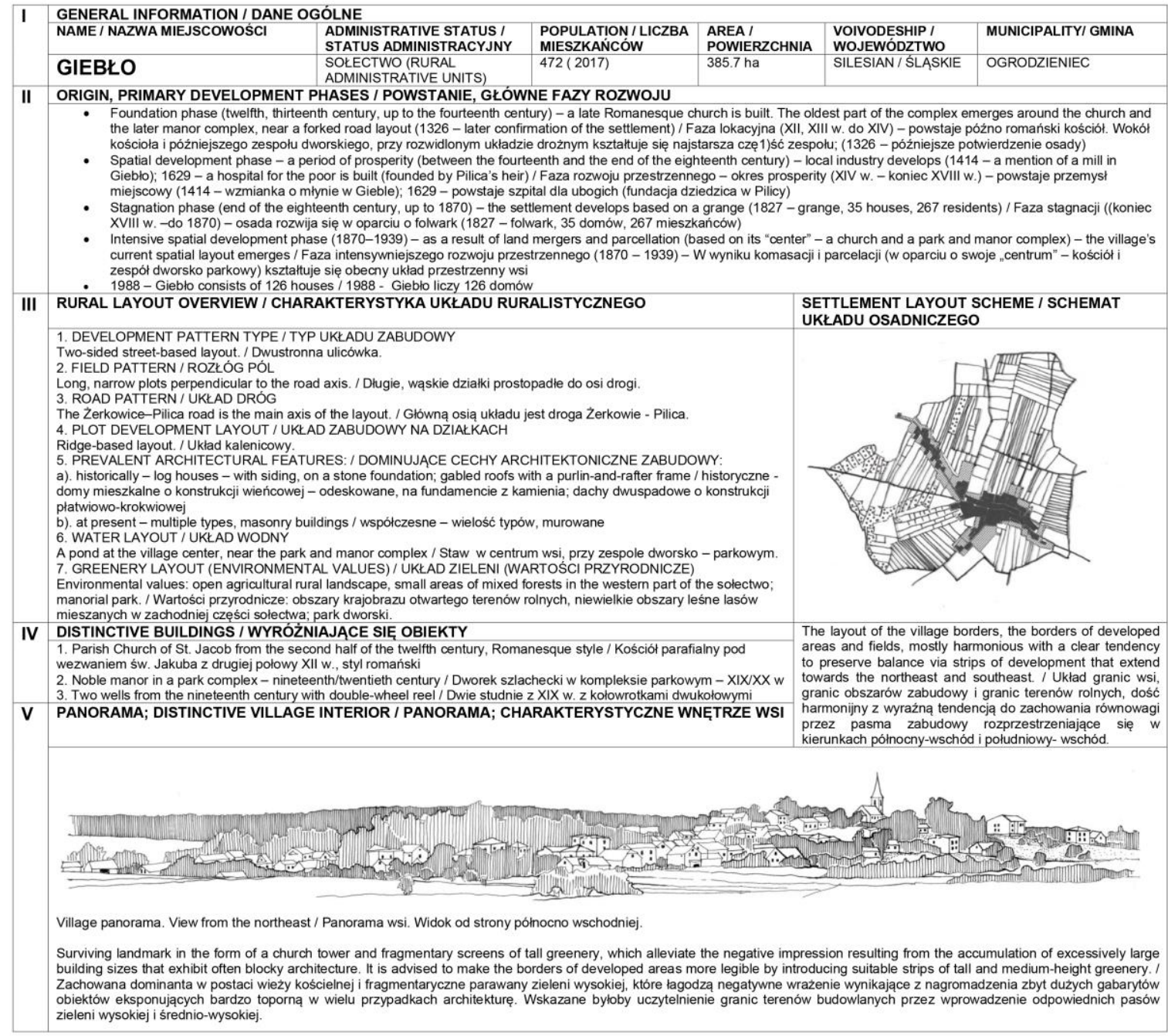

Fig.1 Simplified chart for the village of Giebło. Source: I. Cygankiewicz

Ryc.1 Uproszczona karta wsi Giebło. Źródło: I.Cygankiewicz

Our studies showed that the greatest development dynamic in terms of buildable areas was present in those localities that were delineated at the start of the twentieth century as a part of land consolidation and parcellation, i.e. Fugasówka, Giebło Kolonia, Ryczów Kolonia and thus had the highest number of potentially free, unconfined areas for development. The stimuli that activated this growth were, as our investigation found, completely different: in Fugasówka it was the development of industry, the placement of a railway line and close proximity to powiat town; in Giebło Kolonia it was the development of agriculture; in Ryczów Kolonia it was the development of agriculture and significant development pressure due to highly valuable local wildlife and landscape assets. The three aforementioned solectwa are characterised by a similar form of planning and spatial design, void of any structuring idea whatsoever.

Considerable development dynamics in buildable land were also displayed by solectwa whose agricultural function was marginalised in favour of the development of tourism. Podzamcze is one such case, as it has valuable landscape and cultural assets and a relatively low non-agrarian population. The development of areas directly abutting the castle on Góra Janowskiego takes on a particularly invasive form. Despite a precisely outlined zone of castle landscape conservation, new 
projects associated with tourist services are constantly being located there, endangering and partially damaging the natural environment.

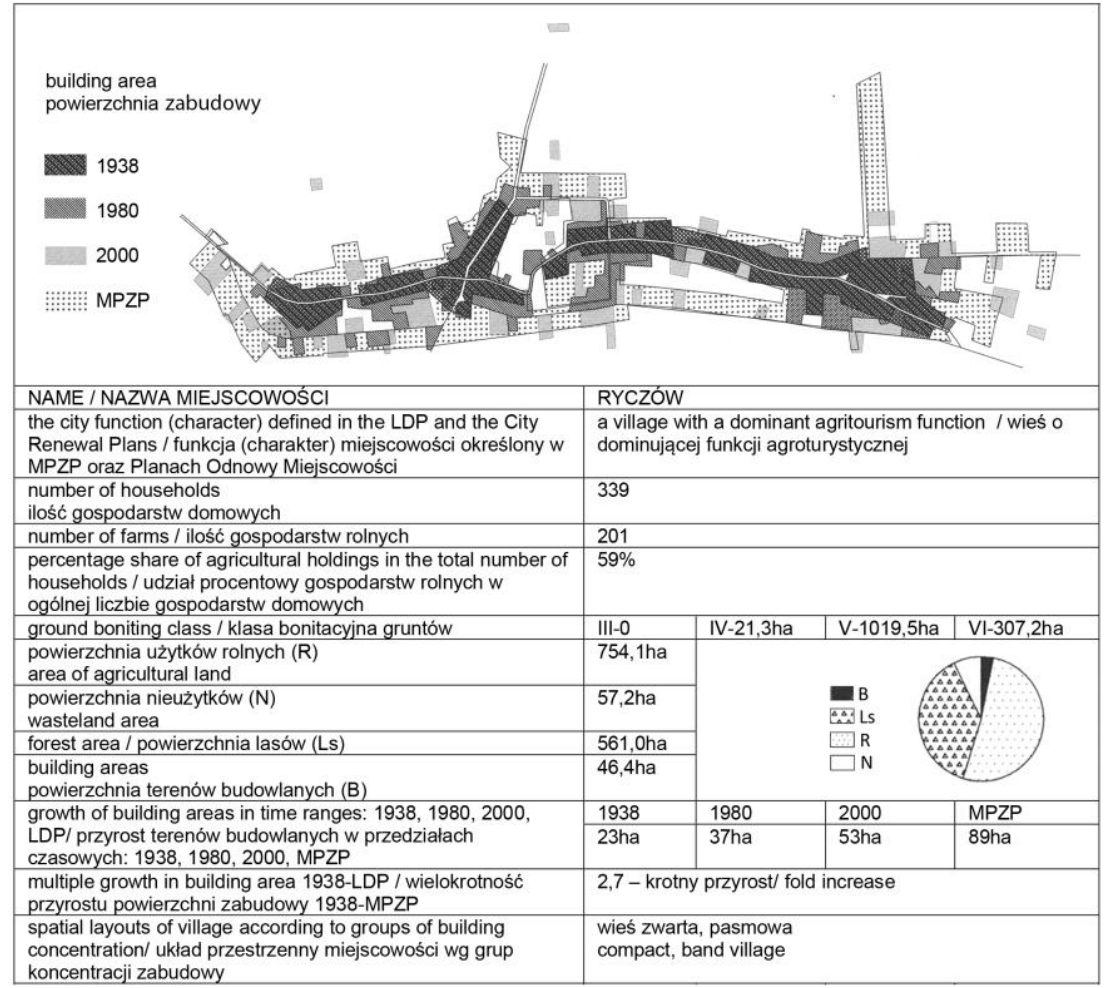

Fig. 2. Village development analysis. Source: I.Cygankiewicz.

Ryc. 2. Analiza rozwoju wsi Ryczów. Żródło: Opracowanie I.Cygankiewicz

The findings of the spatial development analyses of villages in the Ogrodzieniec municipality led to the following conclusions:

A marked growth of developed areas was observed in localities with a predominantly non-agrarian population: Fugasówka, Podzamcze, Śrubiarnia, Żelazko. The exception here is the sołectwo of Giebło Kolonia, where a relatively high growth in development was dictated by introducing considerable land area reserves for the agrarian population in the local spatial development plan.

The increase in buildable land for the non-agrarian population was significantly tied with the development of tourism-related (Żelazko, Podzamcze) and hotel functions (Śrubiarnia). The close proximity of a locality that is the seat of the powiat and the development of industry and services stimulated excessive growth of buildable land (Fugasówka). The lowest increase in buildable land was observed in villages where the agrarian function predominated (Gulzów, Mokrus, Giebło).

The using up of previously undeveloped land reserves for development and construction expressed itself primarily by extending development along main and utility toads and the scattering of buildings.

The development of settlement is considerably conditioned by demographic tendencies. A population growth prognosis allows for a correct determination of potential future size of buildable land demand.

When one analyses data for the Ogrodzieniec municipality it can be observed that changes in population numbers were characterised by different intensities in the town and in rural areas. In Ogrodzieniec itself, the number of residents constantly increased up to 2010 , while in rural areas 
positive growth was present up to the end of the 1980s. Afterwards, a downwards trend predominated.

From among the 10 sołectwa analysed, only two, Fugasówka and Podzamcze, displayed a continuously positive population growth up to 2010. In Fugasówka this was associated with, as previously mentioned, the process of industrialisation and urbanisation, while in Podzamcze this trend applied mostly to the landscape and cultural attractiveness of the village and developing tourism.

In terms of demographic development, the locality of Mokrus is notable, as it had a higher population in 1885 (population of 317) or in 1921 than it has now.

When we compare the demographic data with the results of analysis of the spatial development of each village's built-up area, we can conclude that negative demographic trends in the rural areas of the Ogrodzieniec municipality were not reflected in the pace of growth of buildable land. Applicable local spatial development plans increased buildable land severalfold or over tenfold in localities whose populations declined or increased very little.

\section{CONCLUSIONS}

Over the past several decades, the rural areas of the Ogrodzieniec municipality underwent significant landscape change. The development of settlement and a departure from agricultural land use have had a key impact on these changes.

Rapidly developing single-family housing, mostly on the basis of increased interest from incoming, non-agrarian population, generated the greatest amount of functio-spatial and compositional and landscape problems.

In terms of settlement layout legibility, Fugasówka was found to rank the worst among the sołectwa investigated, as the boundaries of built-up areas, agricultural and forest areas formed in it a most chaotic composition that will be very difficult to properly structure in the future. The relatively most legible planning layout was found in the village of Mokrus. Its existing utility roads quite clearly delineated the development boundary. Equally legible compositions that positively contrast with extensive agricultural use areas could also be observed in Giebło and Gulzów.

Despite our study's negative findings, the vast majority of villages in the Ogrodzieniec municipality, amounting to $92 \%$, had large or medium-scale assets that allowed for implementing the notion of ViaSP. Only in one case (that of Fugasówka) would this idea be very difficult to implement (although not completely ruled out) due to a relatively high degree of the area's urbanisation, compositional and landscape illegibility and an outright pathological fragmentation of agricultural, meadow and forest areas, among others. The research presented in this work shows the diversity of villages in the Ogrodzieniec municipality. From the standpoint of the ViaSP concept, the relations between agricultural as a once-dominant and now-disappearing economic function of the municipality and non-agricultural forms of employment of rural residents that replace it. The abandonment of agriculture by the rural population leads to numerous changes in all aspects of rural life, be they social, economic, cultural, or, as a consequence, planning, spatial and landscape-related ones.

The conclusions that summarise this discussion on the transitions of settlement in the rural areas of the Ogrodzieniec municipality can be presented in the form of three scenarios that account for three different assumptions that lead to three different transition sequences (Fig.3).

The first, 'realistic' scenario was based on the assumption that the previously mentioned idea of 'a rural park space' will not be implemented in any way, and currently observed major settlement tendencies in the municipality will continue into the future, and their resultant environmental and landscape consequences will follow their previous routes. The growth of buildable land will therefore take place in all villages and shall continue to come at the cost of systematically reduced agricultural land. This is made all the more probable by the fact that no planning document for the Ogrodzieniec municipality has any form of boundary for the spread of settlement. 

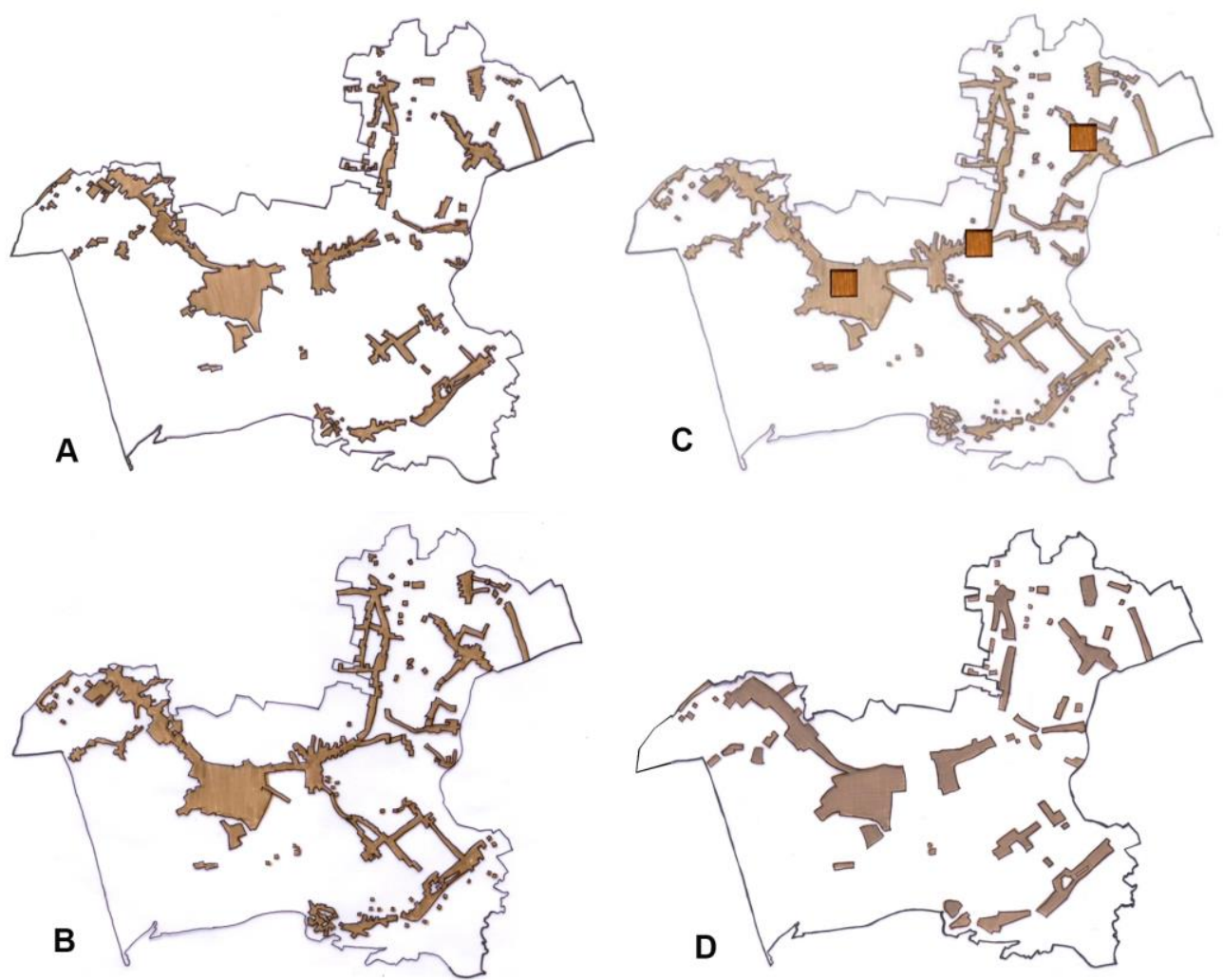

Fig. 3. Scenarios of settlement transformation: A - existing state, B - 'realistic' scenario, C - 'radical' scenario (in the context of the 'realistic' scenario), D - 'moderate' scenario. Source: elaboration I. Cygankiewicz

Ryc. 3. Scenariusze przemian osadniczych: A - stan istniejący, B - scenariusz "realistyczny”, C - scenariusz "radykalny” (na tle scenariusza realistycznego), D - scenariusz „umiarkowany”. Źródło: opracowanie I. Cygankiewicz.

The second, 'moderate' scenario (fig. 4, 5) assumes the implementation of the major elements of the idea of the 'rural park space', and along with it a more rigorous planning and spatial discipline than the current one, especially in terms of the actual constraint of the potential for building development in a spatially scattered form. The first task would be to maintain the size of buildable land at the level that is currently used. At the same time, an area for high-density housing complexes would be delineated, where residents who do not work in agriculture and want to reside in the countryside could move to. Assuming that the population density of such a complex could reach 150 residents/ha, this would result in an over three times lower land use in comparison to currently built complexes of rural development, where population density typically does not exceed 50 residents/ha. At present, geometrically irregular buildable land with 'jagged' boundary lines should be given structured shapes and the development density within new borders should be increased via densification. The borders of buildable land should be made clearer in terms of composition by forming green strips around them. One benefit of this solution would be the possibility of correcting the skylines of individual villages, when seen from outside, using greenery. Open landscape areas would be compositionally structured and enhanced in environmental terms via the introduction of tall and medium-height greenery that would form screens shielding from the wind and avenues of trees composed with utility roads that would also act as tourist trails. In the fields, modern housing and farming complexes would be placed, hidden by screens of trees and hedges. 


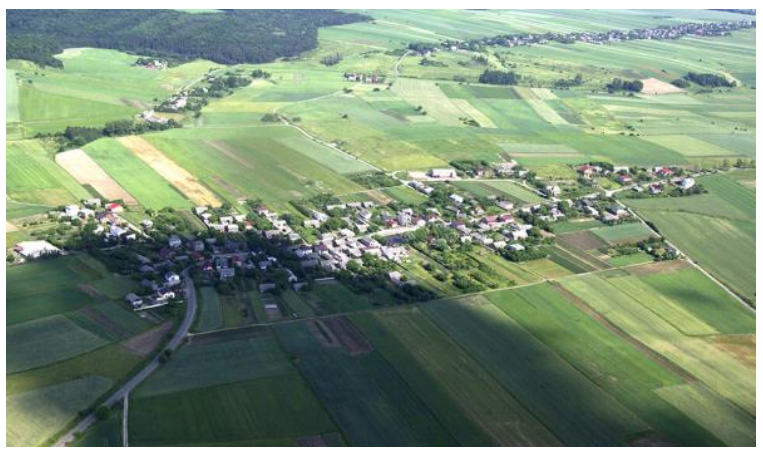

Fig. 4 Mokrus - the existing state. Source: The Ogrodzieniec Municipality

Ryc. 4 Mokrus - stan istniejący. Żrodło: Urząd Miasta i Gminy Ogrodzieniec.

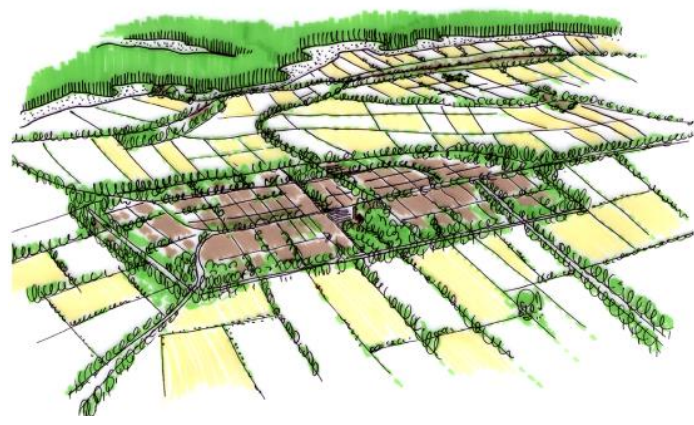

Fig. 5. Mokrus - design sketch made according to the criteria of the idea of "a village in a park space". Source: I.Cygankiewicz

Ryc. 5. Mokrus - szkic projektowy wykonany według kryteriów idei „wsi w krajobrazie parkowym" Źródło: I.Cygankiewicz

The third, 'radical' scenario assumes the gradual but consistently implemented and strong concentration of development for the non-agrarian population that wants to reside in rural areas, which is why the implementation of the notion of 'a rural park space', and thus the preservation of essential environmental, landscape and cultural assets in these areas will be the fullest.

The presented scenarios of planning and spatial transitions and their landscape consequences can be described using the following terms: 'probable' (first scenario), 'cannot be ruled out' (second scenario), 'theoretically possible' (third scenario). These terms make sense in reference to the community of the Ogrodzieniec municipality but could very well be inaccurate when other communities are concerned. Indeed, for the residents of the 'castles' in Haverleij, the third scenario is 'realistic' as the towns were actually built and around them there stretches a green, idyllic landscape, while they do actually inhabit these towns. It can therefore be assumed that the first scenario would be completely 'unreal' to them, as the standards permissible in Ogrodzieniec are completely unacceptable to them. Similarly, the residents of the village of Obertillach in Carinthia (Austria) would find the first scenario 'unreal' for the same reasons as the Dutch, while the second scenario would be quite 'realistic', as the village is surrounded by a landscape that has for generations been shaped and composed by the community in such a way that it now has all the characteristics of a park space.

The sensible planning of the wildlife and landscape environment that local communities inhabit is an outcome of the influence of numerous circumstances, including, and perhaps most importantly, the factor of the correct choice of objective for planning and spatial transitions and the persistent and skilful pursuit of a previously set goal planned for many years ahead.

\section{TENDENCJE W KSZTAŁTOWANIU OSADNICTWA W ŚWIETLE IDEI „WSI W KRAJOBRAZIE PARKOWYM" NA TERENACH GMINY OGRODZIENIEC}

\section{WSTĘP}

W pracach badaczy, wyraźnie widać poważne zaniepokojenie kierunkiem przeobrażeń dokonujących się na polskiej wsi, szczególnie w odniesieniu do tendencji osadniczych realizowanych bez 
respektu dla piękna i wedle nader partykularnych kryteriów użyteczności. Zanik tradycyjnych funkcji wsi, czy też brak dalszych perspektyw rozwoju rolnictwa powoduje, że tereny wiejskie traktowane są w większości jako zasób rozmaitych dóbr przydatnych głównie dla potrzeb urbanizacji. Szczególnym zagrożeniem, mogącym prowadzić do nieodwracalnych strat walorów krajobrazowych wsi, jest ekstensywne, chaotyczne osadnictwo dla ludności nierolniczej, która stanowi coraz większy odsetek współczesnych mieszkańców obszarów wiejskich. W obowiązujących opracowaniach planistyczno-przestrzennych brak jest wizji i pomysłów, które nadążałyby za współczesnymi tendencjami rozwojowymi, szczególnie tymi, które prowadzą do skutków negatywnych z punktu widzenia przyrodniczo-krajobrazowego.

Formą inspiracji dla współczesnych rozwiązań może stać się idea „wsi w krajobrazie parkowym” (WwKP). Może posłużyć jako swoiste narzędzie przy podejmowaniu planistycznych działań naprawczych. W badaniach podjęto próbę określenia na ile ta idea jest aktualna jako metoda działań planistyczno-przestrzennych, jakie są szanse oraz niezbędne warunki do jej realizacji na terenie gminy Ogrodzieniec oraz szerzej, na innych obszarach wiejskich pozostających w zasięgu presji urbanizacyjnej.

\subsection{Metody badawcze}

Artykuł przedstawia w zarysie zasady kształtowania obszarów wiejskich w duchu idei wsi w krajobrazie parkowym (WwKP). Określa zmiany jakie zaszły na terenach wiejskich gminy Ogrodzieniec, które miały istotny wpływ na odbiór przestrzenny wsi.

Na podstawie literatury oraz realizacji ustalono kryteria idei WwKP. Przedstawiono analize wybranych cech osadniczych, krajobrazowych, istotnych z punktu widzenia idei WwKP, zestawiając te dane z czynnikami demograficznymi. Podsumowanie przedstawiono w postaci 3 scenariuszy przemian terenów wsi - realistycznym, umiarkowanym oraz radykalnym.

\subsection{Idea "wsi w krajobrazie parkowym" (WwKP) - zarys}

Idea „wsi w krajobrazie parkowym, nie jest ustawową formą ochrony krajobrazu. Stanowi jedynie pewną koncepcję kształtowania krajobrazu wiejskiego, zgodną z zasadami zrównoważonego rozwoju. Nie jest to idea nowa, jej elementy możemy odnaleźć w różnych opracowaniach studialnych i projektowych począwszy od XIX wieku.

W artykule Autorzy skoncentrowali się na zarysach kształtu owej idei, jaki naszkicowany został w krakowskiej szkole architektury krajobrazu (Z.Nowák, J. Bogdanowski, M.Łuczyńska-Bruzda, K.Dąbrowska-Budziło, Z. Myczkowski, A.Böchm), znajdując swoje dopełnienie w pracach krakowskich ruralistów (A.Rzymkowski, M.Chowaniec, A.Solecki, A.Bocheński, M.Kowicki, M.DrożdżSzczybura). Należy podkreślić, że wiele opracowań szkoły krakowskiej dotyczyło obszaru Jury Krakowsko-Częstochowskiej, a nawet ściśle - obszaru gminy Ogrodzieniec co zdaniem Autorów uzasadnia nawiązanie do wyników tamtych badań.

Za prekursora tej idei - choć dokładnie jeszcze tak nie nazwanej, ale zawierającej szereg jej elementów - uważa się generała Dezyderego Chłapowskiego, który inspirowany podróżami po Anglii i Szkocji założył modelowe gospodarstwo w miejscowości Turew koło Poznania. Z czasem stało się ono dla wielu, nie tylko rolników, wzorem harmonijnego połączenia piękna i użyteczności oraz przykładem planowego kształtowania krajobrazu w celach ekonomicznych (Chłapowski 1852, IInicki 2004, s.163-164).

Pojęcie „krajobrazu parkowego” zostało po raz pierwszy sformułowane w 1976 roku przez prof. Janusza Bogdanowskiego w książce „Kompozycja i planowanie w architekturze krajobrazu”. Zasadniczym walorem powstałej wizji modelowego wiejskiego krajobrazu miała być zwarta zabudowa wsi o cechach budownictwa regionalnego na tle rozłogu pól i zadrzewień śródpolnych, dodatkowo powiązana wzajemnie ze sobą bezkolizyjną siecią drogową ważną dla turystyki pieszej i kołowej.

Prof. Mieczysław Chowaniec wspomnianemu zagadnieniom sanacji wsi poświęcił istotną część swojego dorobku naukowego (Chowaniec 1960, 1963, 1967, 1986). Modele modernizacyjne opracowane przez Profesora polegały na uwolnieniu otwartego krajobrazu wsi od zabudowy rozproszo- 
nej. Nowa zabudowa była skoncentrowana w pasach, równoległych do zabudowy istniejącej i obejmowała obszary położone w izochronie 10-minutowego dojścia pieszego do wyznaczonego ośrodka społeczno-usługowego.

Koncepcje w podobnym duchu, tworzył także August Bocheński (Rzymowski i Bocheński 1963, Bocheński 1968). Zasady re-kompozycji krajobrazu wiejskiego polegały na wprowadzeniu pasmowego typu zabudowy i zespołów zieleni związanej z zagrodowymi działkami siedliskowymi. Projektowane pasy drzew i krzewów miały nie tylko poprawić warunki mikroklimatyczne i zwiększyć dochodowość gospodarstw ale również podnieść wartość estetyczno-krajobrazową terenów i ukryć w krajobrazie zagrody rozproszone.

Próba scalenia różnych elementów dotyczących idei wsi w krajobrazie parkowym rozproszonych w wielu pracach naukowych, pojawiła się w pracy Marka Kowickiego „Wieś przyszłości jako alternatywa osadnicza miasta" (1997), gdzie silnie został zaakcentowany problem mieszkalnictwa dla ludności nierolniczej. Kowicki zwracał uwagę, że wcześniej na ziemiach polskich istniały przykłady intensywnego osadnictwa nierolniczego na obszarach wiejskich (m.in. miasteczka rzemieślnicze i kupieckie) a współcześnie taki system niestety nie jest wdrażany. ${ }^{3}$

Autorzy zwracają uwagę, że w przeanalizowanej przez nich literaturze istnieje zasadniczo jednomyślny postulat radykalnej przebudowy wiejskich układów osadniczych, jako warunku podstawowego modernizacji zagospodarowania obszarów wiejskich w sposób łączący harmonijnie Piękno z Użytecznością.

Model skupionego osadnictwa na obszarach wiejskich, odpowiadający założeniom „wsi w krajobrazie parkowym” i innym związanym z prawidłowym zagospodarowaniem obszarów wiejskich, jest realizowany w krajach zachodniej Europy, a w szczególności w tych rejonach gdzie ziemia jest najbardziej ceniona ze względu na jej deficyt.

Przykładem niezwykle świadomej i racjonalnej gospodarki kształtowanej przez człowieka jest Holandia. Doświadczenia zdobyte przez jej mieszkańców w procesie mozolnego pozyskiwania terenów depresyjnych pomogły w prowadzeniu właściwej gospodarki przestrzennej. Polityka ta szczególnie wiązała się z poszanowaniem przestrzeni otwartych, wolnych od zabudowy. W praktyce oznaczało to wyznaczenie nowych terenów pod inwestycje dopiero w momencie kiedy istniejące uległy całkowitemu wypełnieniu.

Nowe potrzeby ludności pragnącej bliskości natury a jednocześnie wymagającej wygód miejskich stały się inspiracją dla nowatorskich struktur w Haverleij, gdzie zrealizowano projekt nowoczesnych osiedli dla ludności nierolniczej. Koncepcja skoncentrowania zabudowy w formie nawiązującej do średniowiecznych zamków miast-twierdz była pomysłem arch. Sjoerd’a Soeters oraz arch. krajobrazu Paul'a van Beek. Założenie łączy ze sobą komfort, bezpieczeństwo i przestrzeń. Celowo zaprojektowany różnorodny krajobraz, bogaty w łąki, pola trzcinowe, rozległe ogrody, pola golfowe, zbiorniki wodne, sprawia wrażenie „wiejskości”. Skoncentrowana zabudowa, połączona siecią komunikacyjną, wokół której rozciągają się otwarte przestrzenie jest modelem osadniczym, który daje mieszkańcom bliski kontakt z naturą. Być może to rozwiązanie wydaje się być zbyt radykalnym do zastosowania w Polsce w chwili obecnej, ale zapewne wnosi doświadczenie , które być może w przyszłości zaowocuje równie śmiałą i pomysłową realizacją.

Podobny przykład osiedla może stanowić Julianadorp. Odmiennie zaprojektowane aniżeli wcześniej wspomniane Haverleji bo opierające się na sekwencji dość swobodnie rozmieszczonych, kolejno po sobie następujących wnętrz - ale z zewnątrz prezentujące się jako zwarty kompleks na tle otwartego krajobrazu rolniczego.

Innym przykładem świadczącym o potrzebie tworzenia bardzo zdefiniowanych pod względem planistyczno-przestrzennym struktur osadniczych jest Poundbury koło Dorchester w Anglii (Krier

3 Autor posłużył się przykładem Frampola przy przeliczeniach potencjalnej powierzchni zabudowy dla ludności nierolniczej. Przyjął skalę zapotrzebowania terenu pod obszar miasteczka to ok. 250 mieszkańców/ha, wg zasady „nisko-gęsto” co dało wynik 1500-2000 mieszkańców na powierzchni 6-8ha. Okazało się, że przy przyjętej wielkości maksymalnej miasteczka ok.15ha jego teren mieści się na działce 400x400m, a więc mniejszej niż Frampol (500x500m). (Kowicki , Wieś przyszłościjako alternatywa osadnicza miasta, 1997, s. 162) 
2011). Jest to zwarte osiedle o wyraźnie ukształtowanej granicy, oddzielającej teren zabudowy od krajobrazu otwartego. Aby uzyskać odpowiedni klimat tego miejsca projektanci zdecydowali się na bardzo precyzyjne zdefiniowanie zabudowy włącznie z detalem architektonicznym.

Wzorem niezwykle trwałej formy osadniczej może być też wieś Milton Abbas w Dorset w Anglii (Sharp 1946, s. 22). Wybudowana w 1786 r. zachowała swoją zwartą zabudowę dzięki pierścieniowi plant, który skutecznie ochronił ją przed rozprzestrzenieniem się zabudowy poza wyznaczony schemat urbanistyczny.

W wielu regionach Europy zabudowa zagrodowa jest w sposób planowy rozproszona wśród areałów uprawowych - co potwierdzają założenia przyjęte przez M. Kowickiego dotyczące struktury planistyczno przestrzennej osadnictwa ludności rolniczej. Przykłady tego rodzaju planowego rozproszenia znaleźć można łatwo w Holandii, Austrii, Danii, Niemczech i innych krajach kultywujących dobre rolnictwo (Kowicki 2010).

\subsection{Kryteria idei „wsi w krajobrazie parkowym” (WwKP)}

Na podstawie opracowań teoretycznych i realizacji zebrano następujące kryteria dla prawidłowego zagospodarowania obszarów wiejskich łączącego harmonijnie Piękno z Użytecznością (zgodne z ideą "wsi w krajobrazie parkowym"):

1.czytelne zdefiniowanie w opracowaniach planistycznych i realizacjach geometrii obszarów budowlanych, 2. czytelnie poprowadzone linie rozgraniczające tereny budowlane od terenów rolnych, planowe rozproszenie zabudowy dla ludności rolniczej zsynchronizowane $z$ wielkością areałów rolnych, 3. wypracowanie modelu osadnictwa dla ludności nierolniczej np. w postaci miasteczek (istniejących i projektowanych na surowym korzeniu), 4. wyznaczanie i realizacja architektoniczna centrów wsi jako „punktów odniesienia” dla strefowania funkcjonalnego na obszarach wiejskich, 5. wprowadzenie zasad strefowania funkcjonalnego na obszarze wsi w tym: stref ochrony zabytkowych układów planistyczno-przestrzennych, zespołów przyrodniczo-krajobrazowych itd., 6. zachowanie walorów istniejących (parki dworskie i wiejskie, aleje drzew), 7. wyznaczenie stref dla rekreacji: indywidualnej, masowej, 8. sprzężenie systemu dróg gospodarczych z systemem tras turystycznych i systemem zieleni śródpolnej, 9. dbałość o zachowanie naturalnego krajobrazu na wyznaczonych obszarach i użytków ekologicznych (tereny leśne, bagienne, polany śródleśne itp.), 10. wspieranie bioróżnorodności związanej z systemem zieleni śródpolnej, miedzami, remizami, pasami wiatrochronnymi, szachownicą pól, 11. stymulowanie rozwoju rolnictwa ekologicznego lub integrowanego, 12. dbałość o walory kompozycyjno-krajobrazowe: kształtowanie panoram, dbałość o dominanty krajobrazowe, wnętrza wsi, harmonię kolorystyczno-materiałową, tworzenie punktów, ciągów widokowych, 13. tworzenie warunków ekonomicznych motywujących do pielęgnacji walorów przyrodniczo-krajobrazowych i kulturowych, 14. traktowanie pracy rolników nie wyłącznie w kategoriach ekonomicznych ale także docenianie ich roli jako opiekunów krajobrazu.

\section{PRZEMIANY PLANISTYCZNO-PRZESTRZENNE I ARCHITEKTONICZNE NA OBSZARZE GMINY OGRODZIENIEC}

\subsection{Uwarunkowania}

Gmina Ogrodzieniec, ze względu na dużą wartość otaczającego krajobrazu, należy do rejonów atrakcyjnych pod względem osadniczym. Wynika to m.in. z położenia w niedalekiej odległości od trzech głównych aglomeracji Polski południowej: Krakowa $(60 \mathrm{~km})$, Katowic $(55 \mathrm{~km})$, Częstochowy (50km). Obszar Gminy znajduje się w granicach Zespołu Jurajskich Parków Krajobrazowych Województwa Śląskiego, a jednocześnie Parku Krajobrazowego Orlich Gniazd. Wśród wartości kulturowych najwyższą rangę reprezentują, dominujące nad okolicą, ruiny XIV-wiecznego Zamku Ogrodzieniec. W skład gminy wchodzi miasto Ogrodzieniec i 10 sołectw: Fugasówka-Markowizna, Giebło, Giebło Kolonia, Gulzów, Kiełkowice, Mokrus, Podzamcze, Ryczów, Ryczów Kolonia, ŻelazkoŚrubarnia. 
Wybór gminy Ogrodzieniec jako obszaru badań dokonany został ze względu na występujące tam, niemal wszystkie charakterystyczne dla wielu wsi polskich uwarunkowania, z których najważniejsze, to:

- nadal stosunkowo aktywne funkcje rolnicze, jednak z powodu braku koncepcji modernizacji rolnictwa, pozbawione dalszych, wyraźnych perspektyw rozwojowych (zmiana stosunku do ziemi, która ceniona jest bardziej, jako teren budowlany, niż jako areał rolny),

- rosnący odsetek ludności pozarolniczej zamieszkującej na obszarach wsi (typowe przejawy rurbanizacji: dojazdy do pracy, wieś jako „sypialnia”, migracja ludności miejskiej na obszary wiejskie, osłabienie więzi społeczno-terytorialnych itd.),

- występowanie funkcji rekreacyjnych i możliwość ich intensyfikacji

- tendencje do rozpraszania zabudowy,

- nieczytelność rygorów planistyczno-przestrzennych i architektonicznych

- eksploatacyjne, a nie opiekuńcze formy korzystania z walorów przyrodniczo-krajobrazowych obszarów wiejskich.

Gmina Ogrodzieniec, ze względu na dużą wartość otaczającego krajobrazu, należy do rejonów atrakcyjnych pod względem osadniczym. Wynika to m.in. z położenia w niedalekiej odległości od trzech głównych aglomeracji Polski południowej: Krakowa $(60 \mathrm{~km})$, Katowic $(55 \mathrm{~km})$, Częstochowy (50km). Obszar Gminy znajduje się w granicach Zespołu Jurajskich Parków Krajobrazowych Województwa Śląskiego, a jednocześnie Parku Krajobrazowego Orlich Gniazd. Wśród wartości kulturowych najwyższą rangę reprezentują, dominujące nad okolicą, ruiny XIV-wiecznego Zamku Ogrodzieniec. W skład gminy wchodzi miasto Ogrodzieniec i 10 sołectw: Fugasówka-Markowizna, Giebło, Giebło Kolonia, Gulzów, Kiełkowice, Mokrus, Podzamcze, Ryczów, Ryczów Kolonia, ŻelazkoŚrubarnia.

\subsection{Historyczne przemiany planistyczno-przestrzenne}

Proces zasiedlania obszarów i powstania najstarszych i najważniejszych zespołów osadniczych, znajdujących się obecnie w gminie Ogrodzieniec nastąpił już w XIV wieku, a zasadniczy układ sieci osadniczej został uformowany na przełomie XIX/XX wieku (Cygnarowski i Jagodziński 1991).

Wg badań archeologicznych obszarami zajętymi najwcześniej przez osadnictwo były: Podzamcze (funkcjonujące bardzo wcześnie jako zespół służebny zamku), Kiełkowice, Giebło (kościół istniał już w połowie XII w.) i Ryczów. Do najstarszych osad na terenie gminy zalicza się również Ogrodzieniec (w 1337 r. posiada kościół parafialny), oraz Mokrus.

Tempo zmian uległo przyspieszeniu gdy w początkach XX w. w wyniku parcelacji wielkich majątków ziemskich i komasacji gruntów powstały dodatkowo zespoły osadnicze: Kolonia Ryczów, KoIonia Giebło, Morusy oraz niewielkie skupiska zabudowy rozproszonej w innych zespołach. W tym czasie uzyskał również kształt Gulzów, funkcjonujący dotąd jako folwark w dobrach pilickich. Stosunkowo najpóźniej ukształtował się zespół osadniczy Markowizna i Fugasówka. Były to silne bodźce pobudzające tendencje do rozpraszania zabudowy na obszarach wiejskich. Uległy one dalszemu wzmocnieniu w wyniku przeprowadzonej w przededniu II Wojny Światowej komasacji i parcelacji gruntów. Jednak pomimo tego rozproszenie zabudowy, szczególnie duże w sołectwie Kiełkowice, nie niosło jeszcze wówczas ze sobą zbyt drastycznych skutków kompozycyjnokrajobrazowych. Nadal nie zmieniano bowiem skali poszczególnych budynków wznoszonych na wsi ani też ich formy architektonicznej, w wielu przypadkach nadal powielając w lekko zmodyfikowanej formie tradycyjne rozwiązania funkcjonalno-przestrzenne i materiałowo-konstrukcyjne.

Największy przełom niosący ze sobą zasadnicze zmiany planistyczno-przestrzenne i architektoniczne nastąpił w latach 1960-1980. Charakteryzował się on m.in. wysokim tempem rozwoju budownictwa mieszkaniowego wspieranym dodatkowo polityką kredytową, oraz gotowymi rozwiązaniami projektowymi. Żywiołowy rozwój zabudowy nie zintegrowanej z otoczeniem był wówczas głównym czynnikiem kształtującym krajobraz wsi.

W latach 80-tych sposób formowania zabudowy wpływał już w bardzo istotny sposób na charakter planistyczno-przestrzenny gminy Ogrodzieniec. Potwierdzeniem tego może być zapis w Studium 
Planu Szczegółowego Zagospodarowania Przestrzennego Sołectwa Ryczów, dotyczący problemu kształtowania obiektów mieszkalnych i ochrony krajobrazu, sugerujący o bezpowrotnej utracie i zniszczeniu wartości przyrodniczo-kulturowych badanego obszaru: $W$ chwili obecnej, niewłaściwe decyzje dotyczące lokalizacji, formy i funkcji realizowanych obiektów, doprowadziły do niekorzystnego rozproszenia zabudowy mieszkalnej, poprzez lokalizowanie jej w atrakcyjnych krajobrazowo punktach, co przy obecnej tendencji budowy trzykondygnacyjnych sześciennych brył, zdegradowato ostatecznie walory krajobrazowe wsi i jej sąsiedztwa." (Gałkowski,Tomaszewska, 1984, s.70)

Okres od lat 90-tych XX, aż po dzień dzisiejszy przyniósł żywiołowy rozwój zabudowy cechujący się różnorodnością form architektonicznych. Przeobrażenia planistyczno-przestrzenne w tym okresie wynikały głównie z: łatwiejszej dostępności terenów budowlanych na wsi - niewielka wartość ziemi w porównaniu do działek miejskich, rozwoju transportu i nasilenia ruchu samochodowego wpływającego bezpośrednio na rozluźnienie powiązań między mieszkaniem a miejscem pracy, pojawieniem się nowych możliwości na rynku pracy oraz atrakcyjności przyrodniczo-krajobrazowej obszarów wiejskich, szczególnie w porównaniu z coraz trudniejszą sytuacją ekologiczną miast.

\subsection{Analiza rozwoju przestrzennego zabudowy wsi w gminie Ogrodzieniec}

Przeprowadzono analize wybranych cech osadniczych i krajobrazowych istotnych z punktu widzenia idei WwKP, w oparciu o metodę uproszczonych "kart wsi" 4 (Myczkowski, 1998) dla gminy Ogrodzieniec (ryc. 1). Ujęte w postaci tabelaryczno-rysunkowej zestawienia wszystkich miejscowości, miały na celu przedstawienie: danych ogólnych (status administracyjny, liczba mieszkańców, powierzchnia ogólna w granicach administracyjnych); charakterystyki układu ruralistycznego (określenie głównych faz rozwoju wsi, charakterystyki głównych elementów układu ruralistycznego: typologii układu planistycznego zabudowy, której dokonano na podstawie studiów historycznokonserwatorskich gminy Ogrodzieniec (Cygnarowski, Jagodziński, 1991) z uwzględnieniem systematyki osadnictwa (Kiełczewska-Zalewska, 1972), rozłogu pól, orientacji budynków mieszkalnych na działkach, cech architektonicznych, a także elementów krajobrazowych tj. wody powierzchniowe i zieleń; schematu układu osadniczego na tle rozłogu pól i obszarów leśnych; charakterystyki wybranych, najważniejszych problemów kompozycyjno-krajobrazowych dla danego obszaru wiejskiego.

Przedstawiono także w postaci tabelarycznej (ryc.2) analizę rozwoju przestrzennego zabudowy gminy Ogrodzieniec (dla każdego z sołectw, łącznie z miastem Ogrodzieniec), która pozwoliła określić wymiar obszarowy, tempo i kierunki przestrzenne dotychczasowych zmian w poszczególnych wsiach gminy w następujących sekwencjach czasowych: 1938-1980-2000-horyzont określony w Miejscowym Planie Zagospodarowania Przestrzennego.

Układy przestrzenne wsi zamieszczone $w$ tabeli scharakteryzowano posługując się typologią opracowaną przez M. Chilczuka (Chilczuk, 1970). Przyjęto podział wg stopnia koncentracji zabudowy na układy: a). zwarte, w których co najmniej 2/3 ogólnej liczby zagród znajduje się w odległości 20$30 \mathrm{~m}$ od siebie, b). skupione w których odległość $2 / 3$ zagród (odległość od budynków mieszkalnych) mieści się w granicach 50-70m od siebie, c). rozproszone, gdzie odległość pomiędzy zagrodami w 2/3 wynosi średnio 120-180m lub więcej. Poszukując czynników od których zależy rozwój przestrzenny osiedli wiejskich w analizach podano również charakter miejscowości zgodny z jej obecną funkcją i określoną w dokumentach gminnych, ilość gospodarstw domowych i procentowy udział w nich gospodarstw rolnych, klasę bonitacyjną gruntów oraz aktualne, dokładne powierzchnie użytków rolnych, nieużytków lasów i terenów budowlanych.

Porównanie danych przedstawionych w ujęciu tabelarycznym doprowadziło do następujących wniosków odnośnie do badanych grup wsi:

\footnotetext{
4 Uproszczone karty wsi opracowano na podstawie Instrukcji do metryki szczegółowej, Wieś-Ruralistyka, Metryka 7.1, bazującej na tzw. Kartach wsi (szczegółowe - M. Łuczyńska-Bruzda, Z. Myczkowski z zespołem, 1988; uproszczone J. Bogdanowski, 1989) [w:] Ochrona wartości krajobrazu i środowiska kulturowego, Praca zbiorowa pod kierownictwem Z. Myczkowskiego, 1998, Krajobrazy 18 (30), Ośrodek Ochrony Zabytkowego Krajobrazu, Narodowa Instytucja Kultury, Warszawa.
} 
Przeprowadzona analiza rozwoju przestrzennego wsi w gminie Ogrodzieniec, która wykazuje przyrosty terenów zabudowanych w przekrojach czasowych: koniec lat 30-tych, koniec lat 70-tych, początek XXI wieku oraz przyrosty planowane, wykazuje wyraźny przyrost terenów zabudowanych w miejscowościach, gdzie dominuje ludność nierolnicza, natomiast we wsiach o dominacji funkcji rolniczej te przyrosty są stosunkowo najmniejsze. Spośród 10 sołectw można wyodrębnić zaledwie trzy, które posiadają znamiona dyscypliny planistycznej. Są to zespoły ruralistyczne Gulzowa, Mokrusa i Giebła. Zabudowa tworzy tam najbardziej zwarte i rozpoznawalne formy w krajobrazie. Z zebranych danych wynika również (UM i G Ogrodzieniec) iż są to miejscowości gdzie udział gospodarstw rolnych jest najwyższy w całej gminie. A zatem praktykowanie rolnictwa sprzyja ochronie przydatnych dla tej funkcji terenów przed zabudowaniem.

Według przeprowadzonych badań największą dynamikę rozwoju obszarów budowlanych wykazują te miejscowości, które zostały wydzielone $z$ początkiem XX wieku podczas procesów komasacj i parcelacji gruntów tj: Fugasówka, Giebło Kolonia, Ryczów Kolonia i w związku z tym miały potencjalnie najwięcej wolnych, nieograniczonych terenów do zainwestowania. Bodźce stymulujące ten rozrost były jednak jak wynika z badań zupełnie różne: Fugasówka -rozwój przemysłu i doprowadzenie nitki kolejowej oraz bezpośrednie sąsiedztwo miasta powiatowego; Giebło Kolonia - rozwój rolnictwa; Ryczów Kolonia - rozwój rolnictwa i znaczny napór inwestycyjny związany z dużymi walorami przyrodniczo-krajobrazowymi tego miejsca. Wspomniane trzy sołectwa charakteryzuje jednak podobna forma kształtowania planistyczno-przestrzennego pozbawiona jakiejkolwiek idei porządkującej.

Znaczną dynamikę rozwoju obszarów budowlanych wykazują także sołectwa, których funkcja rolnicza została marginalizowana na rzecz rozwoju turystyki. Takim przykładem może być miejscowość Podzamcze, które odznacza się wysokimi walorami krajobrazowymi i kulturowymi, oraz stosunkowo niedużą liczbą ludności nierolniczej. Szczególnie inwazyjną formę przybiera zabudowa terenów położonych w bezpośrednim sąsiedztwie zamku na Górze Janowskiego. Pomimo ściśle określonej strefy ochrony krajobrazu zamku, powstają tam wciąż nowe inwestycje związane z obsługą ruchu turystycznego, zagrażające i częściowo niszczące środowisko przyrodnicze.

Wyniki analiz rozwoju przestrzennego wsi w gminie Ogrodzieniec prowadzą do następujących wniosków:

Wyraźny przyrost terenów zabudowanych występuje w miejscowościach gdzie dominuje ludność nierolnicza tj. : Fugasówka, Podzamcze, Śrubiarnia, Żelazko. Wyjątek stanowi tutaj sołectwo Giebło Kolonia, gdzie stosunkowo duży przyrost zabudowy podyktowany jest wprowadzeniem w MPZP znacznych rezerw powierzchniowych dla ludności rolniczej. Zwiększenie obszarów zabudowy dla ludności nierolniczej wiąże się znacząco z rozwojem funkcji turystycznej (Żelazko, Podzamcze) oraz letniskowej (Śrubiarnia). Bodźcem stymulującym nadmierny przyrost terenów budowlanych jest bliskie sąsiedztwo miasta powiatowego, rozwój przemysłu i usług (Fugasówka) Najmniejsze przyrosty terenów zabudowanych obserwuje się we wsiach w których dominuje funkcja rolnicza Gulzów, Mokrus, Giebło). Zużywanie zasobów terenów dotychczas niezabudowanych na cele inwestycyjno-budowlane, wyraża się głównie przez rozciąganie zabudowy wzdłuż dróg głównych i gospodarczych oraz rozproszeniem obiektów.

Rozwój osadnictwa jest w znacznym stopniu uwarunkowany tendencjami demograficznymi. Prognoza rozwoju ludności pozwala na prawidłowe określenie potencjalnych, przyszłych wielkości terenów budowlanych. Analizując dane odnośnie gminy Ogrodzieniec, można zaobserwować, że zmiany liczby ludności charakteryzowały się odmienną intensywnością w mieście i na terenach wiejskich. W samym Ogrodzieńcu liczba mieszkańców do 2010 r. stale wzrastała, podczas gdy na terenach wiejskich dodatni przyrost występował do końca lat 80-tych. Po tym okresie wystąpiły tendencje spadkowe.

Spośród 10 sołectw tylko dwa, Fugasówka i Podzamcze, wykazywały do 2010r. stale dodatni przyrost liczby ludności. W Fugasówce wiązało się to, jak wcześniej już wspomniano, z procesem uprzemysłowienia i urbanizacji, natomiast w Podzamczu trend ten dotyczył głównie atrakcyjności krajobrazowo-kulturowej wsi i rozwijającej się turystyki. 
Pod względem rozwoju demograficznego uwagę zwraca miejscowość Mokrus, w której w roku 1885 (317 osób) czy też w 1921r. odnotowano większą liczbę mieszkańców niż jest to w chwili obecnej.

Porównując dane demograficzne $z$ wynikami analiz dotyczącymi rozwoju przestrzennego zabudowy poszczególnych wsi, można stwierdzić, że spadkowe tendencje demograficzne na obszarach wiejskich gminy Ogrodzieniec nie mają odzwierciedlenia w tempie przyrostu terenów zabudowanych. Obowiązujące plany zagospodarowania przestrzennego zwiększają kilkukrotnie lub kilkunastokrotnie powierzchnię pod zabudowę w odniesieniu do miejscowości, których liczba ludności wciąż maleje lub przyrost mieszkańców jest nieznaczny.

\section{WNIOSKI}

Tereny wiejskie gminy Ogrodzieniec w przeciągu ostatnich kilkudziesięciu lat uległy znaczącym przemianom krajobrazowym. Istotny wpływ na te zmiany wywarł rozwój osadnictwa oraz odejście od rolniczego sposobu użytkowania ziemi.

Żywiołowo rozwijające się mieszkalnictwo jednorodzinne, głównie na bazie rosnącego zainteresowania ludności napływowej, nierolniczej, wygenerowało najwięcej problemów funkcjonalnoprzestrzennych i kompozycyjno-krajobrazowych.

Pod względem czytelności układu osadniczego wśród badanych sołectw najgorzej wypada Fugasówka, gdzie granice zabudowy, obszarów rolnych i leśnych utworzyły najbardziej chaotyczną kompozycję i niezwykle trudną w przyszłości do uporządkowania. Stosunkowo najbardziej czytelnym układem planistycznym jest wieś Mokrus. Istniejące tam drogi gospodarcze dość jednoznacznie wyznaczyły granicę zainwestowania. Równie czytelne kompozycje w pozytywny sposób kontrastujące z rozległymi powierzchniami użytków rolnych można także zaobserwować w obrębie wsi Giebło i Gulzów.

Mimo negatywnych przesłanek z przeprowadzonych badań wynika, że znacząca większość, bo aż 92\% badanych wsi w gminie Ogrodzieniec posiada duże, bądź średniej skali walory umożliwiające realizację koncepcji WwKP. Tylko w jednym przypadku (Fugasówki) idea ta mogłaby być bardzo trudna do zrealizowania (choć nie wykluczona), z powodu dość wysokiego stopnia zurbanizowania tego obszaru, nieczytelności kompozycyjno-krajobrazowej, patologicznej wręcz fragmentacji terenów rolno-łąkowo-leśnych itp.

Przedstawione w pracy badania ukazują zróżnicowanie wsi gminy Ogrodzieniec. Z punktu widzenia idei WwKP szczególnie istotne znaczenie mają relacje pomiędzy rolnictwem, jako dominującą w przeszłości, a dziś zanikającą funkcją gospodarczą gminy, a wypierającymi rolnictwo innymi formami zatrudnienia mieszkańców wsi. Odchodzenie ludności wiejskiej od rolnictwa powoduje liczne zmiany we wszelkich aspektach życia wiejskiego: społecznych, gospodarczych, kulturowych i oczywiście, w konsekwencji także planistyczno-przestrzennych i krajobrazowych.

Wnioski podsumowujące rozważania na temat przemian osadnictwa na terenach wiejskich gminy Ogrodzieniec można przedstawić w postaci trzech scenariuszy uwzględniających trzy różne założenia prowadzące do trzech różnych sekwencji przeobrażeń (ryc.3).

Pierwszy scenariusz, „realistyczny” oparty został na założeniu, że idea wspomnianego wcześniej „wiejskiego krajobrazu parkowego" nie będzie realizowana w żaden sposób, obecnie obserwowane główne tendencje osadnicze na obszarze gminy będą kontynuowane w przyszłości, a wynikające z tego konsekwencje przyrodniczo-krajobrazowe toczyć się będą dotychczasowymi, utartymi koleinami. Przyrost terenów budowlanych odbywać się będzie zatem we wszystkich wsiach, nadal kosztem uszczuplanej systematycznie powierzchni obszarów rolnych. Jest to tym bardziej prawdopodobne, że nigdzie, w żadnym opracowaniu planistycznym dla gminy Ogrodzieniec nie wyznaczono nieprzekraczalnych granic dla rozprzestrzeniającego się osadnictwa.

Drugi scenariusz, (ryc. 4,5) „umiarkowany” zakłada realizację głównych elementów idei „wiejskiego krajobrazu parkowego", a wraz z tym, bardziej rygorystyczną niż obecnie dyscyplinę planistyczno-przestrzenną, szczególnie w zakresie faktycznego ograniczenia możliwości realizacji zabudowy 
w rozproszeniu przestrzennym. Pierwszym zadaniem byłoby zatem zamrożenie wielkości terenów budowlanych na tym poziomie jaki jest aktualnie wykorzystany. Jednocześnie należałoby wskazać tereny dla osiedli intensywnej zabudowy mieszkaniowej do których mogliby przeprowadzić się ci mieszkańcy, którzy nie pracując w rolnictwie chcieliby jednak mieszkać na wsi. Zakładając, że gęstość zaludnienia takiego osiedla może wynieść np. $150 \mathrm{M} / \mathrm{ha}$, dałoby to ponad trzykrotnie mniejsze zużycie terenu w porównaniu z obecnie realizowanymi zespołami zabudowy wiejskiej, gdzie gęstość zaludnienia na ogół nie przekracza $50 \mathrm{M} / \mathrm{ha}$. Obecne, nieregularne geometrycznie tereny budowlane o „łamanych” liniach rozgraniczających powinny uzyskać umiarowe kształty a intensywność zabudowy w nowych granicach powinna być podniesiona przez dogęszczenie zabudowy. Granice terenów budowlanych powinny być uczytelnione kompozycyjnie przez stworzenie wokół nich pasów zieleni. Walorem takiego rozwiązania byłaby możliwość korygowania przy pomocy zieleni sylwet poszczególnych wsi oglądanych z zewnątrz. Obszary krajobrazu otwartego zostałyby uporządkowane kompozycyjnie i wzbogacone pod względem przyrodniczym przez wprowadzenie systemów zieleni wysokiej i średniowysokiej tworzącej parawany wiatrochronne i aleje drzew komponowane z drogami gospodarczymi funkcjonującymi także jako ciągi turystyczne. Wśród rozłogu pól, osłonięte parawanami drzew i żywopłotów umieszczone zostałyby nowoczesne zespoły mieszkalno-zagrodowe.

Trzeci scenariusz, „radykalny” zakłada stopniową ale konsekwentnie realizowaną, silną koncentrację zabudowy dla ludności nierolniczej, która pragnie mieszkać na obszarach wiejskich, dzięki czemu realizacja idei „wiejskiego krajobrazu parkowego”, a więc i ochrona istotnych walorów przyrodniczo-krajobrazowych i kulturowych tych obszarów będzie najpełniejsza.

Przedstawione scenariusze przeobrażeń planistyczno-przestrzennych i ich krajobrazowe konsekwencje określić można przymiotnikami: „prawdopodobny” (scenariusz pierwszy), „niewykluczony” (scenariusz drugi), „teoretycznie możliwy” (scenariusz trzeci). Te przymiotniki mają sens w odniesieniu do społeczności gminy Ogrodzieniec, ale niekoniecznie będą trafne w odniesieniu do innych społeczności. Oto bowiem, dla mieszkańców „kaszteli” w Haverleij scenariusz trzeci jest „realistyczny" ponieważ miasteczka zostały rzeczywiście zbudowane, wokół nich rozciąga się zielony, sielski krajobraz, a oni w tych miasteczkach naprawdę mieszkają. Można natomiast przypuszczać że scenariusz pierwszy byłby dla nich absolutnie „nierealny” ponieważ w Holandii nie akceptuje się takich standardów planistycznych jakie dopuszczalne są w gminie Ogrodzieniec. Podobnie, dla mieszkańców wsi Obertilliach w Karyntii (Austria) „nierealny” byłby z tego samego powodu co dla wspomnianych Holendrów scenariusz pierwszy, natomiast całkiem "realistyczny" jest scenariusz drugi, bowiem wieś otacza krajobraz od pokoleń kształtowany i komponowany przez ich społeczność w taki sposób, że posiada on dziś wszelkie cechy krajobrazu parkowego.

Sensowne kształtowanie środowiska przyrodniczo-krajobrazowego w jakim żyją społeczności lokalne jest wypadkową oddziaływania wielu okoliczności, w tym także, może nawet $w$ zasadniczej mierze, tego czynnika jakim jest trafny wybór celu realizowanych przeobrażeń planistycznoprzestrzennych, a w ślad za tym upartego, rozpisanego na wiele lat, umiejętnego dążenia do wytkniętego celu.

\section{BIBLIOGRAPHY}

Bocheński A., 1968 a, Z aktualnych zagadnień zabudowy wsi, Budownictwo wiejskie, Państwowe Wydawnictwo Rolnicze i Leśne, $\mathrm{Nr} 6$, s. 12-14

Bocheński A., 1968 b, Zagospodarowanie przestrzenne terenów rolniczych, Budownictwo wiejskie, Państwowe Wydawnictwo Rolnicze i Leśne, Nr 8, s. 3-4

Bogdanowski J., 1976, Kompozycja i planowanie w architekturze krajobrazu, PAN, Wrocław, Warszawa, Kraków, Gdańsk.

Bogdanowski J., Łuczyńska-Bruzda M., [Novák Z.], 1973, Architektura krajobrazu, PWN, Warszawa-Kraków.

Chilczuk M., 1970, Osadnictwo wiejskie Polski, PWN, Warszawa.

Chłapowski D., O rolnictwie, Poznań 1852

Chowaniec M.,1986, Zarys teorii i zasad kształtowania osiedli i terenów wiejskich, Politechnika Krakowska, Kraków. 
Cygankiewicz I., 2015, Wieś w krajobrazie parkowym, [w:] Problemy kształtowania planistycznokrajobrazowego i architektonicznego obszarów wiejskich, Czasopismo Techniczne, Architektura 1-A/2015, Politechnika Krakowska, s.5-26

Cygnarowski A., Jagodziński Z., 1991, Studium konserwatorskie gminy Ogrodzieniec, Zespół osadniczy Fugasówka i Markowizna, Giebło, Gulzów, Kiełkowice, Mokrus, Podzamcze, Ryczów, Ryczów Kolonia, Śrubarnia i Żelazko, Kraków.

Drożdż-Szczybura M., 2013, Prognozy przekształceń obszarów wiejskich [w:] P.Raźnia (red. nauk.), Społeczno-ekonomiczne przemiany regionów, Wydawnictwo Krakowskie, Towarzystwo Edukacyjne, Oficyna Wydawnicza AFM, s. 83-116.

Gałkowski A., Tomaszewska E., 1984, Jura Krakowsko-Częstochowska, Studium kształtowania form zabudowy, Wydawnictwo albumowe, Katowice.

Kowicki M., 2011, O wątpliwych i niewątpliwych pożytkach z badań naukowych na temat wsi w planowaniu przestrzennym i architekturze [w:] M.Halamska (red.), Wieś jako przedmiot badań naukowych na początku XXI wieku, Centrum Europejskich Studiów Regionalnych i Lokalnych, Uniwersytet Warszawski, Wydawnictwo Naukowe Scholar, Warszawa, s. 73-87

Kowicki M., 2010, Patologie/wyzwania architektoniczno-planistyczne we wsi małopolskiej. Studium na tle tendencji krajowych i europejskich, Wydawnictwo Politechniki Krakowskiej.

Kowicki M., 2014, Rozproszenie zabudowy na obszarach wiejskich Małopolski a kryzys kreatywności opracowań planistyczno-przestrzennych, Wydawnictwo Politechniki Krakowskiej, Kraków.

Kowicki M., 2005, Wieś przyszłości - próba określenia jej kształtu planistyczno-przestrzennego i architektonicznego, [w:] J.Wilkin (red.), Polska wieś 2025. Wizja rozwoju, Wydawnictwo Fundusz Współ-pracy, Warszawa, s. 199-207.

Kowicki M., 1997, Wieś przyszłości jako alternatywa osadnicza miasta, Monografia 242, Wydawnictwo Politechniki Krakowskiej, Kraków.

Krier L., 2011, Architektura wspólnoty, Leon Krier and Dhiru Thadani, Gdańsk.

Kulaga K., Michalski K.A., 1984, Studium Planu Szczegółowego Zagospodarowania Przestrzennego Sołectwa Ryczów, ZPiUI INWESTPROJEKT, Śląsk.

Rzymkowski A., Bocheński A., 1963, Wykorzystanie siedlisk zagród rozproszonych, Budownictwo wiejskie, Państwowe Wydawnictwo Rolnicze i Leśne, nr 1, s. 12-14.

Rzymkowski A., Chowaniec M., 1972, Ruralistyka. Planowanie obszarów rolniczych i budownictwo wiejskie, Arkady, Warszawa.

Sharp T., 1946, The anatomy of the village, Penguin Books, Harmondsworth, Middlesex.

\section{AUTHORS' NOTE}

Ingeborga Cygankiewicz - is a lecturer at the Faculty of Architecture at the Cracow University of Technology. In her research, she deals with the issues of shaping rural areas.

Jan Łaś - is a lecturer at the Faculty of Architecture at the Cracow University of Technology. He conducts research on wooden architecture, in particular from the Podhale region. He has extensive design and implementation experience.

\section{O AUTORACH}

Ingeborga Cygankiewicz - jest pracownikiem dydaktycznym na Wydziale Architektury na Politechnice Krakowskiej. W badaniach podejmuje problematykę kształtowania terenów wiejskich.

Jan Łaś - jest pracownikiem dydaktycznym na Wydziale Architektury na Politechnice Krakowskiej. Prowadzi badania dotyczące architektury drewnianej w szczególności z terenów Podhala. Posiada duże doświadczenie projektowe i wykonawcze.

Contact | Kontakt: cygankiewiczingeborga1@gmail.com; jan.las@pk.edu.pl 